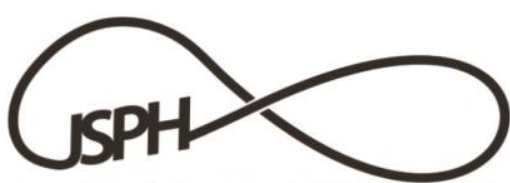

P-ISSN : 2502-7875 E-ISSN : 2527-5879

\title{
AKTUALISASI PEMUDA DALAM PROPAGANDA POLITIK DI DUNIA VIRTUAL Nur Idayati ${ }^{1}$, Femiana Afkarina Program Studi Sosiologi Fakultas Ilmu Sosial dan Ilmu Politik Universitas Jember \\ 1Email : nuridayati11@gmail.com
}

\begin{abstract}
Abstrak
Artikel ini memfokuskan pada isu pemuda, politik dan Reality of The Virtual. Secara konseptual argumentasi yang dibangun oleh peneliti merujuk pada kehidupan pemuda hari ini, tidak terlepas dari perkembangan teknologi terutama yang disebut dengan internet. Era tersebut sebagaimana disebut sebagai revolusi 4.0, merepresentasikan realitas yang tidak lagi didasarakan pada persoalan materialitas, tetapi menempatkan materialitas sebagai bentuk yang dapat direproduksi melalui teknologi. Silang sengkarut antara yang asli dan asali menjadi hal yang tak lagi layak diperdebatkan dalam konteks ini. Apa yang muncul dan direpresentasikan dalam ruang-ruang digital menjadi bentuk pemuda dalam menghadirkan dirinya atau strategi eksperimentasi. Di satu sisi politik eksperimentasi ini menjadi bagian dari artikulasi identitas, tetapi di sisi lain persoalan non eksperimentasi patut dipertanyakan secara sosiologis. Dalam konteks ini, narasi subjek digital yang hadir dalam Reality Of The Virtual menjadi krusial, khususnya dalam era politik pemuda yang menempatkan pemuda sebagai objek yang diasumsikan kosong dan direbut oleh jejaring politik. Asumsi kekosongan pemuda merujuk pada pengalaman empiris mereka, khususnya pada posisi historis yang kemudian dikonstruksikan masuk pada era politik popular. Karena, persoalan bagaimana eksperimentasi politik pemuda? Menjadi isu utama yang dinarasikan dengan analisis Michel Foucault tentang relasi kuasa dan Slavoj Zizek tentang Reality Of The Virtual. Sebagai konsekuensi metodologis, analisis diskursif menjadi cara peneliti dalam menarasikan politik pemuda. Dalam penelitian ini, eksperimentasi politik pemuda hadir sebagai konsekuensi dari revolusi 4.0 dan khususnya menjadi cara pemuda untuk merepresentasikan identitasnya.
\end{abstract}

Kata kunci : Diskursus, Eksperimentasi, Kuasa, Politik Pemuda, Reality Of The Virtual

\section{YOUTH ACTUALIZATION ON POLITICAL PROPAGANDA IN VIRTUAL REALITY}

\begin{abstract}
This article focuses on the issues of youth, politics and the Reality of the Virtual. Conceptually the argument built by the researcher refers to the youth's life today is inseparable from technological developments, especially the socalled internet. This era as referred to as revolution 4.0, represents reality that is no longer based on the issue of materiality, but places materiality as a form that can be reproduced through technology. The disagreement between the original and the original becomes something that is no longer worthy of debate in this context. What appears and is represented in digital spaces becomes a form of youth in presenting themselves or an experimentation strategy. On the one hand, this political experimentation is part of the identity articulation, but on the other hand the problem of non-experimentation should be sociologically questionable. In this context, the digital subject narrative that is present in the Reality of the Virtual becomes crucial, especially in the era of youth politics which places youth as objects that are assumed to be empty and captured by political networks. The assumption of youth emptiness refers to their empirical experience, especially in historical positions which were later constructed into the era of popular politics. Because of this, the problem is how is the political expansion of youth? Being a major issue is narrated by Michel Foucault's analysis of the power relation and Slavoj Zizek about the Reality of the Virtual. As a methodological consequence, discursive analysis is the way of researchers in narrating youth politics. In this study, youth political experimentation was present as a consequence of revolution 4.0 and in particular became a way for youth to represent their identity.
\end{abstract}

Keyword : Discourse, Experimentation, Power, Politics of Youth, Reality Of The Virtual 


\section{LATAR BELAKANG}

Pemuda, dalam kajian ilmu sosial mendapat perhatian tersendiri, hal ini merujuk pada perdebatan pada: fungsi social; batasan usia atau karakter biologis; kelas sosial; dan politik identitas. Isu tersebut seakan menempatkan pemuda hanya pada persoalan eksistensial dan keterlibatan dalam struktur sosial. Disisi lain politik pemuda dipercaya membentuk suatu counter culture yang mampu berjarak, kritis dan secara objektif dapat menciptakan perubahan. Dalam konteks politik, hal ini kemudian diproyeksikan sebagai ruang partisipatif dengan logika elektoralnya.

Hal ini berkaitan dengan teori-teori tentang pemuda yang ada saat ini mendekati kajian tentang orang muda dalam banyak cara menarik dan kaya, termasuk kepemudaan sebagai transisi, kepemudaan sebagai aksi, kepemudaan sebagai praktik budaya, pemuda sebagai pencipta budaya dalam Jones (White, 2012).

Asumsi pemuda sebagai sebuah generasi yang memiliki kesamaan historis yang sama dalam konteks ini ditempatkan sebagai setting social. Pemuda sebagai sebuah generasi saat ini telah sampai pada perkembangan teknologi digital. Setting ini menjadi isu menarik karena menggambarkan transformasi pemuda dengan teknologi di Indonesia baik secara nasional maupun global. Era digital identik dengan perkembangan teknologi yang cepat dan merubah struktur masyarakat. Manusia mengaplikasikan semua kegiatan dalam satu waktu (multi tasking) dengan teknologi yang mereka gunakan seperti smartphone maupun PC. Mereka tidak bisa melepaskan diri dari "jeratan" IT yang memaksanya harus memilih, menerima atau terlibas.

Perkembangan dan percepatan teknologi komunikasi dan informasi yang begitu masif menyebabkan berbagai informasi dapat diakses dengan mudah di era digital. Salah satunya ialah media sosial (Instagram) sebagai akses untuk dapat hidup dan menjadi bagian dari masyarakat maya. Selain itu media sosial (Instagram) kemudian dijadikan sebagai ajang eksistensi diri dengan status sosial yang menyebabkan perubahan perilaku di dunia maya.

Di era digital, pemuda dihadapkan secara langsung dengan teknologi canggih dan kuantitas pemuda semakin meningkat. Keadaan ini merupakan bentuk dari bonus demografi sehingga dapat dikatakan bahwa pemuda di era digital menjadi sasaran politik di Pilpres 2019.
Saat ini kedua Capres dan Cawapres berosialisasi melalui media. Salah satunya adalah cawapres Sandiaga Uno yang menirukan bahasa Millennial anak "Jaksel" dengan pencampuran IndonesiaInggris di akun Instagramnya dengan berfoto bersama Ridwan Kamil.

Pemuda berperan dalam setiap bidang seperti ekonomi, sosial-politik dan IPTEKS. Dalam bidang sosial-politik, di Amerika keberhasilan Barrack Obama dalam pemilu presiden memperoleh $66 \%$ suara dan John McCain hanya memperoleh $23 \%$ suara yang langsung di pilih oleh generasi muda di bawah usia 30 tahun. Sedangkan untuk di Jakarta, generasi millennial memberikan pengaruh iklim politik yang cukup signifikan menjelang pemilu di tahun 2017, peminat kursi gubernur DKI Jakarta mulai riuh mengisi media massa (Perangin-angin dan Zainel, 2018:738)

Fenomena menarik yang menjadi bahan pemberitaan media adalah peran pemuda di era digital yang mengusung jejaring demokrasi berbasis media dan komunitas online dengan memanfaatkan keleluasaan informasi dan teknologi. Misalnya, jejaring komunitas \#2019TetapJokowi dan \#2019GantiPresiden.

Pada peristiwa di tingkat global maupun lokal, sosial media (Instagram) berperan dalam aspek sosial-politik yang dapat membangun suatu jaringan demokrasi. Jaringan digital menghadapkan pada kemunculan diskursus yang berbeda. Di satu sisi, mereka membangun komunitas untuk menyuarakan aspirasi dan dukungan terhadap calonnya melalui sosial media (peluang). Namun di sisi lain, jaringan komunitas ini dapat menyuarakan isu-isu negatif kepada lawannya. Konsekuensinya, masyarakat digital akan terbagi dalam tiga kutub, yaitu pendukung kedua pasangan dan kutub ketiga adalah ruang antara keduanya yakni posisi mereka yang bersifat netral (Stalker). Fenomena ini berkonsekuensi pada Netizen kedua kutub (pengguna media sosial) yang merupakan pemuda dan pada gilirannya mengeluarkan berbagai komentar termasuk komentar pedas. Bahkan terdapat slogan yang menyatakan bahwa "Maha Benar Netizen dengan segala komentarnya". Artinya pemuda di era digital berkomentar seolah-olah mengerti tentang politik sesungguhnya dengan pemilihan diksi yang kontemporer. Padahal, jika ditelusuri lebih lanjut, mereka hanya mempunyai pengetahuan tentang siapa yang dikomentarinya tetapi tidak dengan pengalaman politiknya. Sesuatu yang kemudian menarik ialah kebimbangan dalam ruang antara 
yang menjadi bagian dari ketiga kutub ini. Hal tersebut semakin menarik karena ruang media sosial mengaburkan antara ruang privat dan publik.

Media sosial dijadikan sebagai ajang untuk menebar kebencian ketika menjelang Pemilu. Tahun 2014 dan 2019 mendatang menjadi berbeda dengan pemilu sebelumnya tahun 2008 karena perbedaan teknologi. Dulu hanya terdapat Facebook dan lain sebagainya dengan tipikalitas media sosial yang sama. Tetapi hari ini ketika teknologi media sosial semakin berkembang, hal ini memberikan wadah bagi jaringan masyarakat maya untuk menyampaikan aspirasinya. Utamanya bagi netizen untuk berbicara tentang politik meskipun mereka tidak mengetahui kondisi yang sebenarnya. Seolah-olah mereka menutup mata dihadapan orang banyak dan berpendapat dengan sesuka hati tanpa memperhatikan dampaknya. Dengan latar situasi tersebut, muncul asumsi bahwa partisipasi politik pemuda semakin meningkat dengan adanya media sosial. Namun persoalannya, apakah hal ini juga sejalan dengan kesadaran mereka? Dan konsekuensi apa yang akan mengikutinya? Apakah media mengubah tatanan pada masyarakat, terutama pola pikir pemuda dalam bersosial media? Adakah konsekuensi lain ketika partisipasi pemuda sudah meningkat, misalnya berbicara tentang moral netizen jika dihubungkan dengan ketiga kutub yang terbentuk pada ruang digital? Tentu hal tersebut tidak terlepas dari pembahasan mengenai kekuasaan dalam politik dan media. Hal ini merujuk pada pemikiran Foucault.

Power is that concrete power which every individual holds, and whose partial or total cession enables political power or sovereignty to be established. This theoretical construction is essentially based on the idea that the constitution of political power obeys the model of a legal transaction involving a contractual type of exchange (hence the clear analogy that runs through all these theories between power and commodities, power and wealth). (Foucault, 1980, p. 89)

Dengan demikian, konsep daily politics merepresentasikan relasi kekuasaan yang membentuk struktur pengetahuan masyarakat. Dimensi kekuasaan politik tidak hanya dalam kajian secara vertikal melainkan pula secara horizontal. Persebaran dan fenomena kekuasaan setidaknya dapat dilihat dari beberapa aspek, yaitu dari dimensi isu, dimensi aktor dan dimensi media (Indriyati, 2012). Dari kekuasaan itulah, muncul virtualitas pemuda yang dikuasai oleh media atau terdapat kuasa yang divirtualkan. Oleh karena itu, penelitian ini ditujukan untuk membangun suatu kritik sosial fenomena yang terjadi menjelang pemilu di tahun 2019, yakni apa yang disebut dengan Politik Non Eksperimentasi dan ill Demokrasi dengan membangun argumentasi tentang polarisasi pemuda di era digital dengan situasi politik. Dengan mengacu pada konsekuensi tingkat partisipasi dan kesadaran politik pemuda di dunia virtual era digital.

\section{METODE PENELITIAN}

Penelitian ini menggunakan perspektif Foucaultian yang memfokuskan relasi kuasa atas pengetahuan maupun pengetahuan atas kuasa. Terutama dalam kajian politik pemuda di era digital dengan tingkat kuasa dan pengetahuan yang mereka miliki. Penelitian ini menggunakan pendekatan diskursif bagaimana wacana membentuk subjek. Sedangkan wacana biasanya dikondisikan oleh institusi-institusi yang lebih dominan. Gordon (dalam Jalal, 2006) menjelaskan pemahaman diskursus Foucault sebagai political commodity, a phenomenon of exclusion, limitation, prohibition.

Artinya, wacana tidak lahir secara alamiah dan tidak pernah netral melainkan telah dibentuk oleh manusia. Dalam hal ini subjektivikasi seringkali hadir dalam kehidupan sosial yang biasanya berwujud kelas dominan dan marjinal. Melalui pertimbangan tersebut, penulis ingin menempatkan bagaimana subjek diposisikan dalam wacana yang terbentuk oleh kuasa pengetahuan terutama di era digital, yaitu media sosial. Subject penelitian ialah mereka yang tergolong sebagai pemuda era digital yang menggunakan media sosial (Instagram dan Youtube) dan mempunyai kreatifitas tinggi terhadap perkembangan politik, terutama dalam upaya kritik.

\section{HASIL DAN PEMBAHASAN}

Ruang Digital Pemuda: Menemukan Yang Baru, Yang Lain dan Yang Lain.

Undang-undang baru tentang kepemudaan mendefinisikan pemuda sebagai "warga Negara Indonesia yang memasuki periode penting pertumbuhan dan perkembangan yang berusia 16 sampai 30 tahun" (UU No.40 Tahun 2009, Pasal 1.1). Kaum muda memiliki konsep tersendiri, terutama jika dilihat sebagai masa transisi dari masa "anak" ke "remaja". Dalam pengertian ini adalah mereka dengan kemampuan membedakan 
mana yang benar dan yang tidak benar atau salah. Selain itu pemuda merupakan masa peralihan ke masa dewasa jika telah mandiri secara ekonomi terlepas dari orangtuanya.

Dalam perspektif modern, menjelaskan bahwa salah satu fase penanda kedewasaan adalah status bekerja secara penuh. Seorang pemuda secara mandiri mampu memenuhi kebutuhannya sendiri, seperti mengambil keputusan sebagai individu serta secara bebas merencanakan masa depannya (Sutopo, 2013:162; Sutopo 2016)

Pengertian lain tentang pemuda dituliskan oleh Abdullah (dalam Wulandari, 2017) mengungkapkan bahwa pemuda atau generasi muda adalah konsep-konsep yang sering diibarati oleh nilai-nilai. Hal ini terutama disebabkan karena keduanya bukanlah semata-mata istilah ilmiah tetapi lebih merupakan pengertian ideologis atau kultural yang tercermin dalam istilah "pemuda harapan bangsa", "pemuda pemilik masa depan" dan "pemuda penerus bangsa".

Pemuda merupakan kelas sosial yang reproduktif. Pemuda menjadi penerus bagi generasi yang telah tua. Pemuda merupakan seseorang yang memimpikan masa depan mapan namun hari ini masih dalam tahap berjuang. Artinya masa depan yang mereka mimpikan pun masih belum pasti. Seperti seorang mahasiswa yang sedang menempuh pendidikan. Mereka berjuang untuk mewujudkan mimpinya. Namun setelah lulus mereka akan dihadapan oleh kondisi persaingan ketat memperoleh lapangan pekerjaan sehingga posisi mereka pun menjadi tidak pasti. Pemuda merupakan semangat zaman, agent of change. Pemuda sering kali disebut sebagai agen perubahan bagi suatu bangsa untuk menjadi lebih baik lagi. Hal ini karena peran pemuda sangat dibutuhkan dalam pembangunan.

Pemuda memiliki peran dalam menciptakan perubahan yang fundamental dalam sejarah bangsa Indonesia karena pemuda dikenal sebagai golongan masyarakat yang idealis dalam mempertahankan apapun yang menurutnya benar dan baik untuk dilakukan. Selain itu faktor umur yang masih panjang memungkinkan pemuda untuk melakukan sesuatu dengan cepat dan dalam waktu yang cukup panjang. (Tampubolon, 2006)

Pemuda merupakan suatu identitas yang potensial sebagai penerus cita-cita perjuangan bangsa dan sumber insani bagi pembangunan bangsanya. Karena pemuda sebagai harapan suatu bangsa dapat diartikan bahwa siapa yang menguasai pemuda maka akan menguasai masa depan. Pemuda hari ini sebagai generasi yang begitu dekat dengan media menjadi pengaruh lain dalam masa depan suatu bangsa. Terutama dihubungkan dengan perkembangan teknologi yang semakin masif, pemuda menjadi begitu kreatif. Misalnya hari ini banyak pemuda yang tampil di media sosial yang disebut YouTube. Mereka berkreasi dengan apik demi rating tinggi. Selain ingin mendapatkan uang dari sejumlah suscribe di YouTube mereka juga mulai menyuarakan tentang politik dalam negeri seperti "vlog". Jadi dari media pun setiap orang dapat menghasilkan uang dengan modal paket data atau wifi dan alat komunikasi seperti android/laptop.

Kata media menurut kamus online Merriam Webster adalah "suatu saluran atau sistem komunikasi, informasi, atau hiburan." Lebih khusus lagi, media massa merujuk pada alat-alat komunikasi yang dirancang untuk mengjangkau sejumlah besar orang (Hernandez, 2007:9). Media massa merupakan fenomena yang relatif baru dalam sejarah umat manusia. Dan hari ini media mulai membentuk apa yang disukai dan tidak disukai oleh pemuda. Media menjadi salah satu sarana yang menyediakan segala macam informasi bagi semua kalangan. Kontrol sosial oleh media massa begitu ekstensif dan efektif sehingga sebagian pengamat menganggap begitulah kekuatan utama media.

Ilmu pengetahuan hari ini bukan sebagai bahan kebenaran melainkan bahan pembenaran. Kemudian yang eksis hari ini bukan tentang prestasi yang dihasilkan melainkan apa yang menjadi atau sedang "viral". Contoh, seorang anak bernama "bowo" yang menjadi viral karena bermain di "Tik Tok". Begitu kuat pengaruh media sosial karena mampu merekayasa kesadaran.

Sebagai contoh, Joseph Klapper melihat adanya kemampuan "rekayasa kesadaran" oleh media, dan ini dinyatakan sebagai kekuatan terpenting media, yang bisa dimanfaatkan untuk tujuan apapun. Rekayasa kesadaran sudah ada sejak lama, namun media-lah yang memungkinkan hal itu dilaksanakan secara cepat dan besar-besaran (Peterson, 2004:39).

Rekayasa kesadaran sebagai contoh dapat digambarkan dari fenomena yang terjadi di pemerintahan kemudian bagaimana hal tersebut dimanipulasi oleh media dengan menyebarkan beberapa berita lain. Hal ini sering disebut sebagai pengalihan isu. Sehingga masyarakat menjadi bingung karena terpancing oleh isu yang salah. Atau masyarakat seolah dibungkam 
dengan beberapa isu lain yang menyebabkan mereka mudah melupakan atau tidak kritis lagi untuk mencari tahu kejadian yang sesungguhnya. Dengan media massa, mereka dapat dengan mudah mengontrol isu-isu yang sedang berkembang di masyarakat.

\section{Cyberspace dan Ruang Digital}

Kata cyber banyak digunakan untuk menjelaskan realitas media baru. Gibson (dalam Nasrullah, 2014:19) kemudian memperkenalkan istilah "cyberspace" untuk menjelaskan bahwa ada tempat di mana ia tidak nyata tetapi keberadaannya dapat dirasakan bahkan menjadi kenyataan dalam benak. Lebih lanjut, Gibson mengemukakan

Hubungan antar-individu di dunia virtual atau di ruang cyber bukanlah sekedar hubungan yang dikatakan sebagai "substanceless hallucination" semata. Pada dasarnya hubungan itu terjadi secara nyata, memiliki arti, dan juga bisa berdampak/berkelanjut pada kehidupan yang sesungguhnya. Dalam cyberspace, netizen dapat bertindak persis sesuai dengan apa yang ada dalam dunia virtual yang disebut dengan virtual reality. Selanjutnya jika mereka menyebarkan hal tersebut kepada orang lain dan diterima hal tersebut merujuk pada apa yang disebut the reality of the virtual.

Tidak ada dunia yang lebih mudah dimasuki selain dari dunia cyber. Tidak diperlukan perizinan, passport dan berbagai pengurusan administrasi. Bahkan tidak harus menggunakan waktu dan biaya besar untuk menempuh perjalanan dalam menjelajah tempat di dalamnya.

Dunia cyber menyajikan banyak informasi berharga, kaya akan aktivitas sosial, transaksi bisnis online berbagai hiburan pun dapat akses melalui cyberworld, selain itu cyberworld pun menyajikan ilusi. Dunia ini memang sangat menarik bahkan banyak diantaranya yang terperangkap dalam dunia ini, menjadikan dunia ini sebagai realita hidup sedangkan dunia nyata sebagai kebalikannya, atau dikenal dengan istilah internet addict ((kecanduan internet)) (Sulianta, 2010).

Menjadi netizen sangat mudah, tidak ada penolakan bagi siapa pun yang ingin tergabung dalam masyarakat cyber. Masyarakat membawa juga semua atributnya dalam dunia nyata ke dalam cyberworld, termasuk pula kepribadian, jiwa, pemikiran, ide, hasrat, dan ambisi. Mereka mentransalasikan diri ke dalam dunia cyber. Kemudahan inilah yang membuat cyberworld adalah dunia dengan peraturan kewargaan yang longgar, bahkan tanpa peraturan. Semua orang bisa menjadi siapa pun dalam dunia cyber dengan cara menggunakan berbagai macam identitias dengan berbagai macam nama. Seperti akun email yang dibuat dengan mencantumkan identitas buatan. Selain itu tidak ada persyaratan tertentu untuk masuk ke dalam dunia cyber. Semua orang dapat menjadi netizen tanpa harus menjelaskan tujuannya berada di sana.

\section{Media sosial}

Media sosial adalah salah satu jenis dari media cyber. Kehadiran situs jejaring sosial (social networking site) atau sering disebut dengan media sosial (social media) seperti facebook, instagram, twitter, dan skype merupakan media yang digunakan untuk memublikasikan konten seperti profil, aktivitas, atau bahkan pendapat pengguna. Media sosial juga memberikan ruang bagi komunikasi dan interaksi dalam jejaring sosial di ruang cyber. Misalnya fasilitas di facebook, yakni "wall" (dinding) dimana pengguna bisa mengungkapkan apa yang yang sedang disaksikan/dialami, keadaan di sekitar dirinya, hingga bagaimana tanggapannya terhadap suatu situasi, misalnya politik pada saat ini.

Instagram merupakan media sosial yang cenderung menjadi tempat untuk membagikan atau melihat informasi baik berupa gambar maupun video singkat. Setiap pemilik akun instagram ada yang bertujuan untuk melakukan bisnis dan ada juga yang hanya sekedar untuk membagikan foto-foto keseharian mereka. Facebook maupun instagram merupakan tempat umum dalam media sosial karena banyak orang kemudian dapat melihat bahkan berkomentar atas status, foto, maupun video yang telah dibagikan. Mereka yang disebut netizen dapat berkomentar positif dan tidak sedikit pula yang berkomentar negatif.

\section{Politik Identitas Pemuda: Melampaui Etika dan Inersia Jebakan}

Terdapat beberapa hal yang menyebabkan pentingnya etika dalam bermedia sosial. Pertama, pengguna media sosial tidak setara dan berasal dari lingkungan yang sama pula. Kemajemukan pengguna ini semestinya menjadi kenyataan yang mesti dihormati oleh siapa pun yang terhubung di media sosial, bahwa media sosial merupakan ruang publik (public space). Kedua, diperlukan adanya kesamaan dalam memahami teks yang diunggah dalam media sosial. Contoh sederhana dalam kasus ini yaitu emoticons yang merupakan 
ekspresi emosi pengguna di internet yang secara umum dianggap sebagai tanda perwakilan dari emosi yang secara universal diakui oleh pengguna internet. Ketiga, pengguna menghindari flaming atau tindakan mengunggah konten yang bersifat menghasut, memprovokasi, atau menyerang norma yang berlaku, misalnya di dalam grup atau forum.

\section{Artikulasi Pemuda: Jejaring Digital dan Narasi Teknologis}

Hubungan antara individu dan kelompok dalam network society bersifat sangat cair dimana satu individu bisa berinteraksi dengan berbagai sumber. Pada era network society, mobilisasi massa di berbagai gerakan yang mengkritisi suatu keadaan atau kebijakan telah membuktikan kenyataan komunitas maya. Seperti halnya turun ke jalan, mengumpulkan beberapa koin untuk korban bencana alam setelah berdiri beberapa jam di lampu merah jalan raya. Hal ini telah menunjukkan bahwa siapa pun dapat membuat aksi baru. Selain itu di media sosial terdapat beberapa situs yang mencoba mengajak untuk merespon kondisi di dunia nyata.

Sejatinya manusia merupakan makhluk cerdas karena memiliki akal, sehingga dapat mengontrol apa yang akan dilakukan. Namun dengan perkembangan teknologi, manusia hari ini seolah terbius. Kedudukan teknologi menjadi dominan dan siapapun yang tidak dapat mengendalikannya maka hidup mereka hanya akan dikuasai atau dikendalikan oleh teknologi.

Pemuda hari ini tidak pernah lepas dari teknolgi karena beranggapan bahwa dengan teknologi semua dapat diselesaikan dengan lebih mudah. Misal, adanya perkembangan sistem transportasi seperti gojek. Gojek memudahkan setiap orang untuk menuju tempat tujuan tanpa harus menguras kantong. Aplikasi gojek pun menyediakan layanan go food sehingga sangat membantu setiap orang yang sangat sibuk, orang yang tidak bisa masak, dan orang yang ingin menikmati makanan kesukaannya tanpa harus keluar rumah. Dengan era digital jaman juga menjadi semakin canggih. Pemuda seolah dimanjakan dengan perkembangan teknologi yang semakin pesat kian hari.

\section{Multi Tasking}

Pemuda hari ini dikatakan sebagai pemuda yang hidup di era digital lebih canggih dan lebih modern. Mereka dapat melakukan beberapa hal dalam satu waktu yang sama. Misalnya makan sambil membalas whatsapp, belajar atau mengerjakan tugas sambil melihat instagram atau facebook, dan lain sebagainya. Setiap orang tidak dapat berpisah jauh dari gawainya atau gadgetnya. Teknologi telah menguasai mereka dan mereka telah dikendalikan oleh perusahaanperusahaan digital semisal google dan facebook.

Di era digital pemuda lebih sering berkutat dengan androidnya. Mereka lebih sering mengupload foto kesehariannya dan cenderung konsumtif karena termakan oleh iklan-iklan yang tayang dalam media sosial. Teknologi berkembang pesat di seluruh dunia. Salah satunya adalah perkembangan media massa, yaitu ruang bagi setiap orang untuk saling berkomunikasi, berbagi foto aktifitas harian, dan lain sebagainya. Luasnya jangkauan internet seharusnya dapat membuat setiap orang menjadi berwawasan luas. Sebaliknya, mereka cenderung termakan oleh berita hoax dari beberapa sumber yang tidak jelas. Hal ini terjadi ketika seseorang yang bertindak bukan lagi sebagai ukuran kebenaran, melainkan karena viral. Netizen akan membenci apa yang media benci, dan sebaliknya akan mendukung atau mencintai apa yang media promosikan. Kebenaran hari ini bukan dari kebenaran yang dirujuk namun apa yang menjadi viral. Pengetahuan sebagai sumber kebenaran tidak lagi dijadikan sebagai rujukan namun sebagai "pembenaran". Relasi hari ini tidak lagi humanis dan rasional tapi tanda atau hanya sekedar bayang-bayang.

\section{Media dan Politik di Indonesia}

Pemerintahan di Indonesia menganut sistem pemerintahan demokrasi. Demokrasi adalah sistem pemerintahan yang seluruh rakyat turut serta memerintah dengan perantara wakilwakilnya. Ada juga yang menyawatakan suatu sistem politik dimana kebijaksanaan umum ditentukan atas dasar mayoritas oleh wakil-wakil yang diawasi secara efektif oleh rakyat dalam pemilihan-pemilihan berkala yang didasarkan atas prinsip kesamaan politik dan diselenggarakan dalam suasana terjaminnya kebebasan berpolitik (Mayo, 1960).

Sedangkan pengertian demokrasi yang lain melihatnya sebagai sebuah proses kesejarahan suatu bangsa. Tumbuhnya demokrasi di Indonesia di akhir tahun 1920-an ini juga secara monumental ditandai dengan diadakannya Kongres Pemuda, 20 Oktober 1928. Sebuah bukti bahwa sikap demokratis membuat kaum muda meninggalkan pemikiran rasis dan kesukuan, dan lebih mementingkan universalisme kemanusiaan dalam wadah kebangsaan daripada terjebak pada 
perbedaan suku, agama, dan bahasa (Ebyhara, 2010).

Dalam demokrasi modern, komunikasi antar aktor-aktor politik dan warga negara sulit dilakukan secara tatap muka. Oleh sebab itu komunikasi politik dewasa ini dilakukan secara termediasi lewat media massa. Kemudian media juga tidak lagi menjadi sarana komunikasi semata tetapi sekaligus sebagai ruang publik. Media memiliki fungsinya sebagai deliberasi politik dimana warga negara dapat berpartisipasi secara aktif berkat kemajuan teknologi. Keadaan ini didukung oleh semakin independennya ekonomi media sehingga terbebas dari intervensi negara.

Hubungan media dan politik saling mempengaruhi satu sama lain. Artinya, relasi tersebut tidak selalu bersifat kooperatif tetapi dapat juga bertentangan atau berbeda pandangan. Namun yang paling penting dari hubungan tersebut adalah posisi media yang melihat politik di satu sisi sebagai sumber berita sementara di sisi lain sebagai proses yang harus dikritiknya. Persoalannya yang terjadi di lapangan, media dapat menjadi independen dalam menjalankan fungsi kritiknya. Sementara di sisi lain dapat menjadi alat propaganda oleh elit politik. Terlebih untuk mempertahankan posisi politik dan ekonominya, media cenderung mengakomodir perspektif dominan dalam masyarkat. "Power is everywhere" kekuasaan berbasis informasi bahwa selama ada pengetahuan akan ada dominasi.

Kekuasaan menurut Foucault dipandang sebagai relasi-relasi yang beragam dan tersebar seperti jaringan, yang mempunyai ruang lingkup strategis. (Kamahi, 2017) Siapa pun yang dominan di dalam masyarakat dan memiliki kekuasaan dalam ranah politik tentu saja memiliki peluang besar untuk mempengaruhi media atau menjadikan media sebagai alat untuk mempertahankan posisi dan memperebutkan kursi politik. Hal ini terjadi karena posisi media yang semakin cair dan dengan situasi membanjirnya berita palsu (hoax) yang tersebar.

Wolfsfeld (dalam Simamarta, 2014) yang menggagas teori political contest berpandangan bahwa cara terbaik untuk memahami peran media dalam proses politik adalah dengan memperhatikan persaingan terhadap akses media sebagai bagian dari upaya penguasaan politik. Lebih jauh,Wolfsfed mengungkapkan bahwa proses ini melibatkan kelompok-kelompok dalam masyarakat yang berusaha untuk menentang otoritas kekuasaan dan menuntut perubahan politik. Dan bahwa perkembangan dan pertumbuhan media di suatu negara dipengaruhi oleh sistem politik pemerintah di mana media itu beroperasi.

\section{Non Ekperimentasi Politik Identitas}

Digitalisasi telah merambah pada kehidupan saat ini, terutama dalam bingkai pemuda. Era digital memiliki peran yang cukup signifikan terhadap bidang politik karena kuantitas pemuda yang banyak dapat dijadikan sebagai sasaran politik. Tentunya partisipasi dalam politik diharapkan mengalami peningkatan yang signifikan. Penulis mencoba untuk menghubungkan antara perkembangan IT secara khusus 'Instagram' dan 'youtube' dengan pola perkembangan demokrasi di Indonesia serta perilaku pemuda di media sosial dalam era digital. Seperti fenomena aksi Riau akhir-akhir ini yang menghebohkan dunia maya.

Peristiwa yang terjadi pada 10 September 2018 di Riau menjadi berita yang ramai dibicarakan oleh masyarakat digital. Peristiwa tersebut merupakan suatu aksi mahasiswa salah satu kampus swasta di Riau, mereka "Menggelar Aksi" untuk menuntut Jokowi turun dari jabatannya dengan membawa pocong yang dibakar. Dalam aksi tersebut mereka mendesak pemerintah untuk memperbaiki tiga komponen, yaitu: memperbaiki perekonomian bangsa (karena pada saat itu nilai tukar dollar yang meroket hingga tembus 14.819 serta hutang negara yang semakin meningkat), memperbaiki demokrasi Indonesia dengan tidak membatasi konstitusi bagi setiap warga negara melalui kekuatan yang dimilikinya, dan mengusut tuntas kasus PLTU Riau-1.

Aksi mahasiswa ini merupakan salah satu aksi yang terjadi selama pemerintahan di rezim Jokowi. Mahasiswa menyatakan "pergerakan mahasiswa belum mati". Namun apakah kita bisa mengetahui informasi ini dengan cepat jika tidak tersebar di media terutama media sosial? Hal ini merupakan ciri dari masyarakat postmodern. Perubahan bisa dikontrol oleh teknologi bukan oleh manusia atau post histories. Media sosial memberitakan bahkan mahasiswa merepost kembali di Insta story maupun WA story dalam akunnya. Kini pemuda dihadapkan pada tiga pilihan yakni pro-kontra dan netralitas terhadap aksi tersebut. namun langkah yang dilakukan pemuda ini apakah dalam melakukan aksi dan menjadi Netizen di media sosial baik itu pro, kontra, maupun ruang antara telah terbentuk kesadarannya? Siapakah mereka dalam era digital dan masalah apakah yang sedang terjadi? 
Apakah ribuan orang yang hanya dikerahkan oleh satu orang penguasa? Sedangkan di sisi lain, apakah netizen yang hidup dalam dunia digital hanya mengikuti pola pikir yang secara umum dalam berkomentar di media sosial atas kejadian tersebut.

Ribuan mahasiswa turun ke jalan untuk melakukan aksi. Bagaimana mereka membangun relasi dan mengkonstruksi pikiran dengan jumlah yang begitu banyak, kalau bukan dari tuntutan yang memiliki kuasa atau mereka yang searah dengan pemikiran penguasa? Disini, penulis tidak melihat siapa yang berkuasa atau dia yang mempunyai jabatan. Namun menurut Foucault "Power is everywhere" dimana ada relasi disitu ada kuasa yaitu kekuasaan yang bersifat informasi atau pengetahuan.

Menunjukkan hubungan antara diskursus ilmu pengetahuan dengan kekuasaan. Ilmu pegetahuan dilaksanakan untuk menetapkan apa yang benar. Disini terlihat bahwa kehendak untuk kebenaran adalah ungkapan untuk dari kehendak berkuasa. Terjadi korelasi pengetahuan mengandung kuasa seperti juga kuasa mengandung pengetahuan (Khozin, 2012, hal. 142). Sama halnya dengan peristiwa tersebut, mereka yang mempunyai pengetahuan yang cukup banyak terkait politik di rezim ini, mereka akan mendominasinya. Jadi ribuan mahasiswa bisa dikerahkan untuk melakukan aksi tersebut karena dominasi pengetahuan yang mereka miliki, dengan tingkat partisipasi mahasiswa yang tinggi. Pengetahuan yang mereka dapatkan tidaklah hanya dari proses belajar di kampus melainkan dari media dengan kecepatan dan keluasan informasinya.

Media merupakan alat propaganda dalam menyebarkan informasi. Terutama di era digital media sosial yang digandrungi pemuda yaitu Instragram dan Youtube. Aksi mahasiswa Riau tersebut kemudian menjadi viral. Hal ini disebabkan juga dari pengaruh kekuatan internet sebagai pengembangan jaringan perlawanan pada cyberspace menampakkan kemampuannya untuk menyebarluaskan gagasan antihegemoni dan memunculkan kekuatan massa untuk menuntut mundurnya Soeharto (Prasetyo, 2013:121).

Hal ini merupakan efek dari determinisme teknologi terhadap masyarakat yang telah mencapai tahapan seduksi, dari sekedar alat berevolusi menjadi agen/organisme tersendiri dan kemudian ditasbihkan menjadi penguasa atas masyarakat. Menurut Foucault "Discipline may be identified neither with an institution nor with an apparatus, it is a type of power, a modality for its exercise, comparising a whole set of instruments, techniques, procedures, levels of application, targets; it is a physics or an anatomy of power, a Technology." (Perangin-angin \& Zainal, 2018)

Kini di era postmodern teknologi khususnya media sosial menjadi penguasa di atas manusia. Siapa yang menjadi budak, siapa yang menjadi tuan. Mereka mengikuti apa yang menjadi skenario dari media sosial. Jika menurut media benar maka menurut manusia benar. Artinya media dijadikan sebagai ukuran kebenaran. Akibatnya, akan menebarkan kebencian di media sosial. Sama halnya yang terjadi dengan komentar netizen terkait aksi Riau yang menghebohkan dunia maya tersebut.

Hal ini merupakan tantangan komunikasi politik melalui media sosial, karena hilangya batas-batas status sosial di dunia media sosial. Pada dasarnya media sosial merupakan rimba raya, dan praktis tidak ada peraturan di dalamnya Fitch dalam (Anshari, 2013, hal. 94). Sehingga terciptalah komentar seperti di bawah ini. (Instagram:@ @mahasiswariau.id)-(comment by:mas.tunk) Dari pihak yang mendukung aksi tersebut mengatakan

"sampai kapanpun mahasiswa akan menjadi mimpi buruk peguasa. Mahasiswa yang bergerak berdasarkan hati, bukan berdasarkan gaji. Mahasiswa yang bergerak membawa suara hati suara rakyat. Bukan membungkam suara rakyat" \#hidupmahasiswa \#2019GANTIPRESIDENT.

sedangkan yang kontra

"Abaikan saja.. mereka (siswa) bukan mahasiswa, merea tidak mewakili rakyat, melainkan mewakili isu sesaat yang hembuskan melalui angin-angin ambisius kekuasaan semata.mereka hanyalah cecurut yang kehilangan induknya, yg berbuat onar tanpa tanpa apa yang mereka layaknya bayi babi yang pertama kalinya bisa merangkak dan terlepas dari kandanganya..liar, brutal, dan tidak mengetahui apa yang mereka lakukan”_(instagram:@myindonesia.1)(comment by:lagunabiru_rifaifire2018)

Hari ini pengetahuan yang mereka miliki bukan dijadikan sebagai sumber kebenaran, tapi pembenaran. Ketika komentar mewarnai media sosial 'Instagram' dan 'Youtube' akan menjadi bahan bacaan orang lain, yang bisa jadi mereka menyetujui pendapatnya tanpa dipikirkan kembali. Dunia maya sangatlah buta, siapa yang 
berkomentar jika sesuai kehendaknya akan dibenarkan. Hal ini yang menjadikan pengetahuan menjadi pembenaran bukan kebenaran.

Namun meskipun pemasaran politik di media sosial dapat mencapai kelompok besar orang dengan cepat dan efisien, ada kemungkinan bahwa pesan politik di Internet akan mengubah pikiran orang. Satu konsultan politik mengatakan kepada Times, "Benda suci yang semua orang cari saat ini adalah bagaimana Anda dapat menggunakan Internet untuk hal persuasif" (Biagi, 2010:353).

Konsekuensinya, adanya ruang antara yang diisi oleh pemuda era digital dengan sikap kenetralannya. Mereka menjadi stalker dan bukan menjadi bagian dari kutub A dan B. Ruang sosial mereka adalah di tengah. Partisipasi pemuda yang semakin meningkat menimbulkan permasalahan baru. Ketika pemuda ruang antara ini kemudian menjadi pemilih yang golput dan dijadikan sasaran untuk menggrogoti ruang privat mereka di media sosial.

Dalam internet, yakni Cyberspace, virtualitas menemukan bentuk sejatinya. Seseorang tidak hanya pasif dalam menerima informasi melainkan mereproduksinya dalam dunia nyata. Bahkan seseorang dapat memvirtualisasikan dirinya dan dunianya. The Illusion to which he succumbs is strictly correlative to the oposite one-to the commonsense attitude of maintening our belief in the full reality outside the virtual universe. That is to say: one should avoid both traps, the simple direct reference to external reality outside cyberpace as well a the opposite attitude of there is no external reality, RL is just another window (Zizek, 1997, hal. 132).

Jika peristiwa aksi mahasiswa di Riau merupakan Reality of the Virtual, mereka memperoleh pengetahuan dari komunitas maupun orang yang memiliki pengetahuan tentang politik. Hal ini merupakan kuasa atas pengetahuan yakni ketika kehadiran cawapres Sandiaga dalam memberikan kuliah umum dan berdiskusi dengan ketua Bem UIR dapat memperkeruh keadaan di Riau sebelum kejadian aksi tersebut. Realitas yang digunakan ialah Reality Of The Virtual karena dia mengalami virtualitas itu dalam kesehariaannya baik di dalam organisasi atau diskusi dengan beberapa tokoh politik. Kemudian hal tersebut direfleksikan melalui pengalaman virtualnya. Sandi mempertegas virtualitasnya dan hal ini yang kemudian digunakan untuk mendorong mahasiswa di Riau turun ke jalan. Aksi ini dimunculkan kembali dalam dunia virtual. Konsekuensinya, akan ada jejaring seperti komentar netizen diatas: kutub a, b dan kutub antara. Jadi, hal ini yang menjadi bayangan yang tidak pernah hadir begitu saja karena virtual ini dikonstruksikan, dan manusia selalu memvirtualisasikan kenyataan. Proses ini berjalan secara simultan. Kebebasan ada dalam ruang cyber yang virtual karena tidak adanya relasi kekuasaan yang menentukan secara etis, estetis dan politis.

Kehadiran teknologi dengan kecanggihannya yang memiliki berbagai akses untuk membentuk jejaring digital telah melampaui batas dimensi inderawi manusia untuk mencerna. Yang terjadi khususnya pada pemuda di era digital yang memiliki sikap "taken for granted" terhadap segala informasi menerima dengan mata tertutup dan mengikuti apa yang telah diberitakan oleh media. Hal ini terjadi pada masyarakat kontemporer.

Media sosial menjadi pilihan utama dalam sosialisasi politik, karena mayoritas pengguna yaitu pemuda yang berada di era digital ataupun masyarakat kontemporer. Mereka menerima informasi yang luas, cepat, seragam dan mereka mudah sekali untuk dipersuasi. Peristiwa politik dari mana saja akan menjadi konsep pengetahuan beberapa jam saja. Sebagian dari mereka membentuk jejaring komunitas di media sosial dan kemudian menjadi penonton tunggal yang memiliki visi dan selera yang sama.

Peristiwa yang telah terjadi di Riau beberapa pekan terakhir merupakan bentuk partisipasi politik yang salah satunya di sebabkan oleh media. Sedangkan, menurut Ted Robert Burr bahwa tindakan kekerasan politik bersifat "episodeik dalam sejarah sebagian besar masyarakat politik dan kronis dalam beberapa masyarakat." (Mas'oed \& MacAndres, 1984, hal. 45). Modernitas tidaklah diukur dengan kecanggihan teknologi semata, melainkan pengguna dari teknologi yang harus canggih. Apa yang mereka lakukan di media sosial jika bisa dijelaskan secara rasional. Dengan demikian dapat dikatakan sebagai orang/pemuda modern. Namun pemuda saat ini terkerangkeng dalam ruang yang dinamakan media sosial dan mengikuti pola pemikiran secara umum di ruang tersebut. Setara dengan diskursus politik, pemuda diharapkan berpartisipasi dengan kebebasan untuk memilih tetapi konstruksi media sosial mendukung untuk menjadi pemuda yang pilihannya selaras dengan media. Jadi, 
subjecttifitas dalam diri pemuda mulai hilang.

Gerakan mahasiswa di Riau merupakan salah satu tindakan terhadap ketidakpuasan kinerja pemerintahan saat ini yang kemudian mengatasnamakan demokrasi. Sistem politik kita ialah demokrasi dengan partisipasi dari rakyat sehingga muncul argumentasi jika partisipasi mulai meningkat akan dipandang lebih demokratis. Bagaimanapun kesadaran subjektivitas tetap harus ada.

Turkle mengintroduksi tentang subjektivitas baru yang bermain dalam ruang simulasi. Subjektivitas baru yang dikonseptualisasikan dengan "eksperimentasi" dengan meletakkan identitas dan materialitas sebagai yang disamarkan dalam virtualitas. Turkle dalam (Prasetyo, 2013, hal. 119). Dalam konteks ini, pemuda di era digital bermain dengan subjektivitas baru yang disamarkan dalam virtualitas. Identitas diri mereka sebagai pemuda yaitu bahwa mereka harus melakukan suatu gerakan yang dianggap mengkritisi keadaan masyarakat saat ini. Hal ini yang akhirnya membuat mereka turun ke jalan untuk melakukan aksi "Melengserkan Presiden" dengan beberapa permasalahan yang ada.

\section{PENUTUP}

Pemuda merupakan kelas sosial yang reproduktif, semangat zaman, dan agent of change. Pemuda hari ini menggunakan media sosial yang menjadi ruang cyber dalam berjejaring sosial. Kemewahan media sosial ini yang kemudian digunakan pemuda untuk mengekspresikan partisipasi politiknya termasuk mengintegrasikan diri secara virtual untuk masuk dalam ruang tiga kutub (pro-kontra dan antara) serta berkontestasi. Pemuda diharapkan dapat menciptakan atau melawan arus, karena di sana terbentuk suatu inovasi.

Tulisan ini merekomendasikan kebijakan yang dibuat oleh pemerintah untuk masyarakat terkait dengan perkembangan teknologi yang begitu masif, untuk membuat perlindungan hukum terkait dengan bagaimana seseorang bermedia sosial dengan tidak menyinggung unsur SARA dan lain sebagainya. Tetapi, pada UU ITE ini hanya berfokus pada subjek saja, bukan korporasi. Karena yang terjadi dalam dunia digital, permasalahan bukan diakibatkan dari individu saja, melainkan suatu kelompok yang dinamakan jejaring komunitas digital.

Pendidikan politik sangat diperlukan dalam membangun karakter pemuda di dunia politik, bagaimana dia berkuasa dengan memahami politik supaya tidak berargumen di media sosial seperti orang yang tidak pernah didik dalam lingkungan sekolah/kampus. Hal ini dapat mempengaruhi sikap politik warganegara terutama pemuda di era digital serta dapat membentuk tingkat kesadaran politik yang bertanggungjawab.

Perkembangan teknologi yang semakin masif membuat pemuda di era digital kehilangan subjektifitas dirinya. Mereka terkendali dengan alat kecil yang bernama smartphone, bahkan pada saat ini kriminalitas digital sangat marak terjadi dengan salah satu ungkapan 'Jempolmu Harimau' yang dulunya dikenal dengan 'Mulutmu Harimaumu'. Artinya terjadi suatu proses transformasi nilai-nilai sosial budaya dari dunia nyata ke dunia virtual. Banyak terjadi kekacauan akibat dari media sosial khususnya dalam menuju pemilu di tahun mendatang. Perdebatan setiap pendukung pasangan calon semakin hangat di perbincangkan. Mereka bebas melalukan apa saja di ruang ini, karena tidak ada kekuaatan yang menentukan harus berargumen seperti apa, bahkan penulis dapat mengatakan bahwa dari yang berkata suci hingga tersuci sekalipun ada di ruang ini. Sebagai generasi muda di era digital apa yang merupakan semangat zaman yang membawa perubahan dan reproduktif ialah menjadikan media diri ini tidak begitu aktif dengan media sosial yang tidak penting, karena sejatinya media sosial itu bersifat reaktif manusialah yang aktif dalam menggunakannya. Jadi, seperti pengandaian sungai yang banyak ikannya, diberikan kail untuk memancing ikan tersebut. artinya, dunia maya banyak yang menggunakan terutama pemuda, dengan konten dan issu politik yang negatif janganlah kita ikut berargumen dengan mereka yang berkata kasar. Karena, sejatinya mereka menyukai ketika komentarnya di respon oleh banyak orang dan bahkan akan mengulangi perilakunya tersebut. Maka "Stop stupied people famous". Karena, bangsa ini tidak akan berubah ke arah yang lebih baik meskipun pemimpinnya telah berganti-ganti. Jika, masyarakat terutama pemuda tidak mempunyai karakter/mental yang baik. Haruslah memilih menjadi pengikut arus atau menciptakan arus dan melawan arus, karena, inovasi itu ada pada orang yang menciptakan atau melawan arus.

\section{Daftar Rujukan}

Anshari, F. (2013). Komunikasi Politik di Era Media Sosial. Jurnal Komunikasi, ISSN 1907-898X, 94. 
Biagi, S. (2010). Media/Impact Pengantar Media Massa . Jakarta : Salemba Humanika.

Ebyhara, A. B. (2010). Pengantar Ilmu Politik. Yogjakarta: Ar-Ruzz Media.

Foucault, M. (1980). Power/Knowledge: Selected Interviews and Other Writings 1972-1977. New York: Pantheon.

Hernandez, R. E. (2007). The Gallup Youth Survey: Isu dan Tren Utama Remaja \& Media. Bandung: Mason Crest Publisher.

Indriyati, R. F. (2012). Politik dan Grafiti. Yogyakarta: Jurusan Politik dan Pemerintahan Universitas Gadjah Mada.

Jalal, M. (2006). Praktik Diskursif The Theory of Truth Michel Foucault dalam Konstruksi Simbolisasi Bahasa di Indonesia.

Kamahi, U. (2017). Teori Kekuasaan Michel Foucault: Tantangan Bagi Sosiologi Politik. Jurnal Al-Khitabah, Vol. III, No. 1, 118.

Khozin, A. (2012). Konsep Kekuasaan Michel Foucault. JurnalTasawuf dan Pemikiran Isalam Volume 2 No 1 , 142.

Mas'oed, M., \& MacAndres, C. (1984). Perbandingan Sistem Politik. Yogyakarta: Gajah Mada University Press.

Mayo, H. B. (1960). An Introduction to Democratic Theory. New York: Oxford University Press.

Nasrullah, R. (2014). teori dan Riset Media Siber (Cybermedia). Jakarta: Kencana Prenadia Group.

Perangin-angin, L. L., \& Zainal, M. (2018, Januari). Partisipasi Politik Pemilih Pemula Dalam Bingkai Jejaring Sosial di Media Sosial. Jurnal ASPIKOM Volume 3 Nomor 4, 738.

Peterson, W. L.-J. (2004). Media Massa \&
Masyarakat Modern. Jakarta: Kencana Prenada Media Group.

Prasetyo, H. (2013, Desember). CYBERPANOPTIC:EKPERIMENTA SI DAN (TRANSPARANSI) KUASA PENGUASAAN. Volume 3 No. 2, hal. 121.

Prisca Kiki Wulandari, D. S. (2017). Membangun Indonesia: Pemberdayaan Pemuda Berwawasan Pancasila. Malang: UB Press.

Simarmata, S. (2014). Media dan Politik: Sikap Pers terhadap Pemerintahan Koalisi di Indonesia. Jakarta: Yayasan Pustaka Obor Indonesia.

Sulianta, F. (2010). Cyberporn Bisnis atau Kriminal. Jakarta: PT Elex Media Komputindo.

Sutopo, O. R. (2013). Hidup adalah perjuangan: Strategi Pemuda Yogyakarta dalam transisi dari Dunia Pendidikan ke Dunia Kerja. Jurnal Sosiologi Masyarakat , 166.

Sutopo, O. (2016). Agenda Pengembangan Kajian Kepemudaan di Indonesia. Jurnal Sosiologi Pendidikan Humanis, 1(2), 161-172. Retrieved from http:// journal2.

um.ac.id/index.php/jsph/article/view/2 472

Tampubolon, P. (2006). Keefektifan Program Pengembangan Karakter Indonesian Youth Leadership Homestay Program untuk Peningkatan Integritas di Gerakan Mari Berbagi. Jurnal Elektronik Mahasiswa PLS Vol 8 No. 5, 330.

White, S. N. (2012). Generasi Antara: Refleksi tentang Studi Pemuda Indonesia. Jurnal Studi Pemuda Vol I No.2 , 89.

Zizek, S. (1997). The Plague of Fantasies . London : Verso. 